\title{
Heterotopic gastrointestinal cyst mimicking chronic cholecystitis: a
}

\section{case report}

\author{
Angel I Popkharitov*1, Maya V Gulubova², Angel D Dandov ${ }^{3}$ and \\ Dimitar P Sivrev ${ }^{3}$
}

Address: ${ }^{1}$ Department of Surgery, Medical Faculty, Thracian University, University Hospital, Stara Zagora, Bulgaria, ${ }^{2}$ Department of General and Clinical Pathology, Medical Faculty, Thracian University, University Hospital, Stara Zagora, Bulgaria and ${ }^{3}$ Department of Anatomy Medical Faculty, Thracian University, University Hospital, Stara Zagora, Bulgaria

Email: Angel I Popkharitov* - popkharitov@abv.bg; Maya V Gulubova - mgulubova@hotmail.com; Angel D Dandov - angel_dandov@mail.bg; Dimitar P Sivrev - dsivrev@yahoo.com

* Corresponding author

Published: 22 May 2008

Journal of Medical Case Reports 2008, 2:173

doi:10.1 186/1752-1947-2-173

Received: I November 2007

Accepted: 22 May 2008

This article is available from: http://www.jmedicalcasereports.com/content/2/I/I73

(C) 2008 Popkharitov et al; licensee BioMed Central Ltd.

This is an Open Access article distributed under the terms of the Creative Commons Attribution License (http://creativecommons.org/licenses/by/2.0), which permits unrestricted use, distribution, and reproduction in any medium, provided the original work is properly cited.

\begin{abstract}
Introduction: Heterotopic gastric mucosa is described almost everywhere in the gastrointestinal tract, from the oral cavity to the rectum. The occurrence of heterotopic gastric tissue in the gallbladder is rare. A choristoma can be defined as a new growth developing from a displaced anlage not normally present in the anatomical site where it developed. We present an extremely uncommon case of a cyst (choristoma) attached to the gallbladder, which contained gastric and intestinal mucosa.
\end{abstract}

Case presentation: A 33-year-old woman was hospitalized with clinical symptoms of chronic cholecystitis. The laboratory findings were within the normal range. Abdominal ultrasonography revealed a thickened gallbladder wall and a stone in the cystic duct was suspected. In the course of laparoscopic cholecystectomy, a cyst was visualized in the vicinity of the duct and the gallbladder neck. Microscopic examination of the removed cyst revealed evidence of gastric, duodenal and small-intestinal mucosa. The immunohistochemical study revealed many endocrine cells, which were positive for several endocrine cell markers such as chromogranin, serotonin, gastrin and so on. It can be inferred that the observed cyst had arisen from the foregut early in the development of the gastrointestinal tract.

Conclusion: The presence of endocrine cells together with epithelial cells supports the hypothesis that these had developed simultaneously, and that the endocrine cells had probably supported the development of the epithelial cells by the release of hormones and growth factors. To the best of the authors' knowledge, this report is the first to report a gastrointestinal cyst choristoma with endocrine cells in the region of the cystic duct and gallbladder.

\section{Introduction}

Heterotopic gastric mucosa is described almost everywhere in the gastrointestinal tract, from the oral cavity to the rectum [1]. The occurrence of heterotopic gastric tissue in the gallbladder is rare, although it has been reported by several authors [2-5]. 
A choristoma can be defined as a new growth developing from a displaced anlage (primordium or first gathering of embryonic cells) not normally present in the anatomical site where it has developed [3].

We present an extremely uncommon case of a cyst (choristoma) attached to the gallbladder, which contained gastric and intestinal mucosa.

\section{Case presentation}

On 5 November 2001, a 33-year-old woman was admitted to hospital with a history of intermittent abdominal pain in the right upper abdominal quadrant, associated with nausea and vomiting. Past medical history revealed incidences of mild complaints of discomfort and pain in the same region radiating to the shoulder and the back. There was no previous history of jaundice.

The physical examination revealed a slight tenderness in the right upper abdomen. Murphy's sign was positive. The tumor markers were negative. The laboratory data were within the normal range.

Abdominal ultrasonography demonstrated a slightly thickened gallbladder wall and a stone in the cystic duct was suspected. We performed laparoscopic cholecystectomy based on the clinical diagnosis of chronic cholecystitis and cholelithiasis.

During laparoscopy, an oval cyst about $2 \times 3 \mathrm{~cm}$ in size was visualized (Figure 1). It was situated in the vicinity of the cystic duct and the neck of the gallbladder and was intimately attached to its wall. The gallbladder itself and

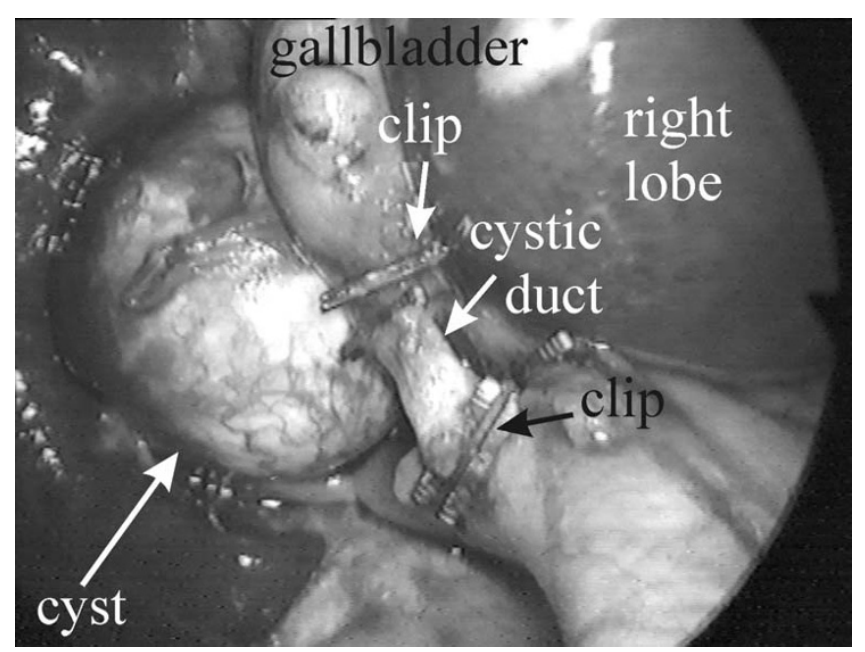

Figure I

Intra-operative image. The cystic duct is dissected and doubly clipped. The gastrointestinal cyst is situated behind and attached to the gallbladder. the cyst were wrapped in fine adhesions, attaching them to the duodenal wall. The gallbladder wall was slightly thickened and inflamed. Laparoscopic cholecystectomy and cystectomy were performed. No gallstones were found. When examined macroscopically, longitudinal resection of the cyst revealed no communication with the gallbladder. The cyst was tightly coalesced to the gallbladder wall. It was filled with a clear yellow fluid. The patient had an uneventful postoperative recovery and was discharged on the second postoperative day in good condition.

The microscopic examination showed that the cyst was flattened and contained mucosa from differing histological types. Gastric mucosa (fundic type; Figure 2A), duodenal mucosa with Brunner glands (Figure 2B) and intestinal mucosa with villi (Figure 2C) were observed. Parts of the mucosa containing cystic glands were chaotically intermingled with connective tissue stroma and small glands. Goblet cells were also seen (Figure 3A).

\section{Immunohistochemistry}

The antibodies used were: rabbit antihuman chromogranin A (N1535), rabbit antihuman synaptophysin (N1566), mouse antihuman synaptophysin (U0037), rabbit antihuman somatostatin (N1551) and mouse antihuman serotonin (N1530), all obtained from DAKO A/S Denmark. The rabbit antihuman gastrin (PA019-5P), rabbit antihuman bombesin (PA062-5P), rabbit antihuman secretin (PA067-5P) and rabbit antihuman beta-endorphin (PA063-5P) were products of BioGenex Laboratories, San Ramon, CA, USA. The detection system used was DAKO LSAB ${ }^{\circledR}$ System, HRP (K0675), and DAKO ${ }^{\oplus} \mathrm{DAB}$ Chromogen tablets (S3000) (DAKO A/S Denmark).

The cyst mucosa showed numerous endocrine cells located in the gastric glands (gastrin, somatostatin and serotonin), the duodenal glands (serotonin, somatostatin, secretin, gastrin and bombesin) and the small-intestinal glands (serotonin, somatostatin, secretin and bombesin). The endocrine cells were also positive for their typical markers chromogranin A, synaptophysin and beta-endorphin. They were dispersed chaotically in the mucosa, some were clustered and others distributed as single cells in the glands. Endocrine cells positive for serotonin are shown in Figure 3B.

\section{Discussion}

A heterotopic gastrointestinal cyst is a rarely observed choristoma, composed of gastric and intestinal mucosa. It has been described mainly in the oral cavity [5], the mediastinum [6] and the retroperitoneum between the stomach and left adrenal gland [7], and is thought to be derived from misplaced embryonal residues. It is usually a cystic formation existing from birth, which is acciden- 


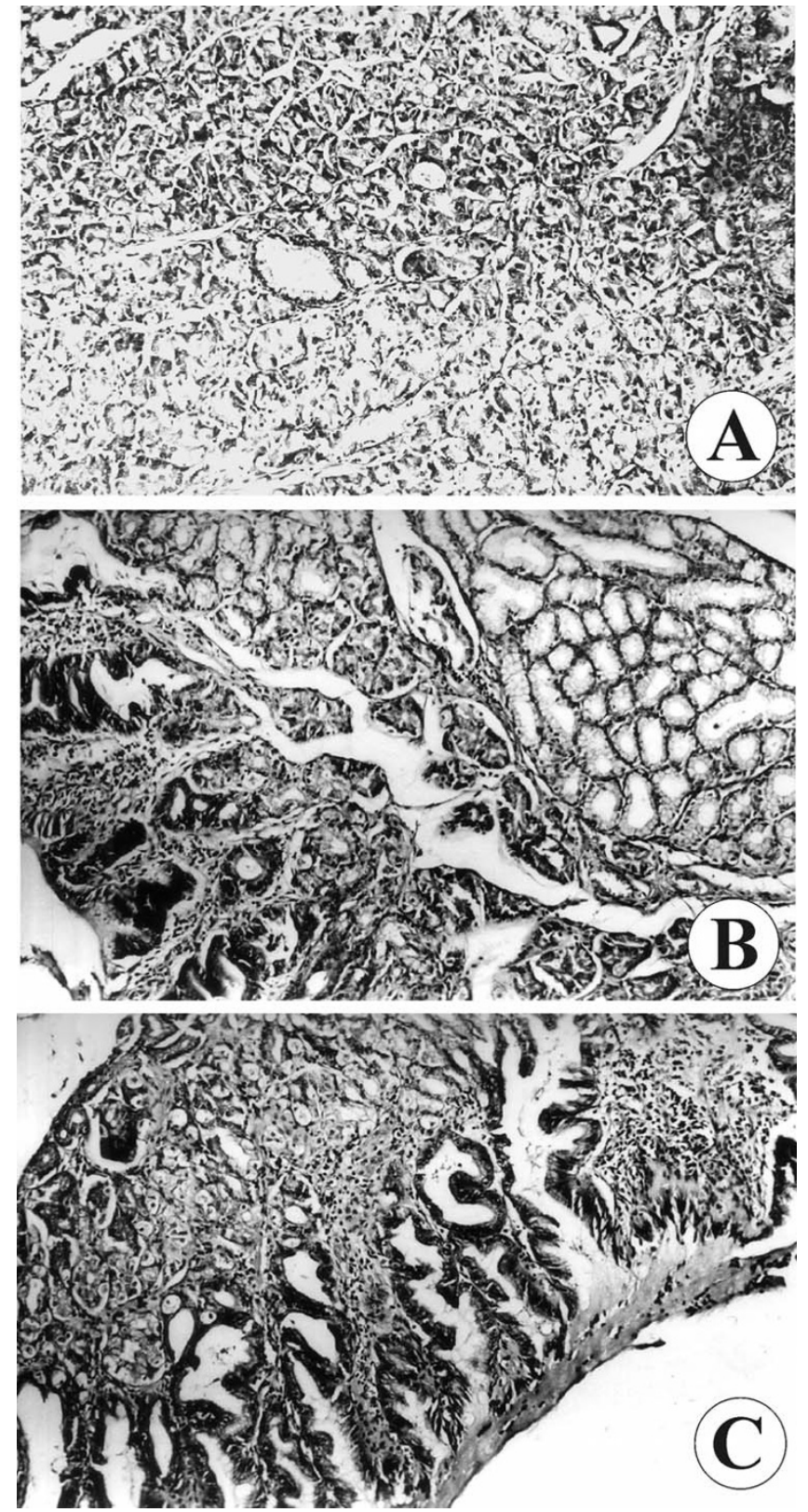

Figure 2

The types of mucosa observed during microscopic examination. (A) Fundic-type and (B) duodenal-type gastric mucosa; $(C)$ intestinal-type villous mucosa.

tally found in the thoracic or abdominal cavity. Histologically, it contains gastric and intestinal epithelium and sometimes also has bronchial mucosa [7].

In our case, a gastroenteric cyst was found in the vicinity of the cystic duct and did not come into contact with the biliary pathways or the duodenum. Histological examination showed that the cyst contained fundic-type gastric

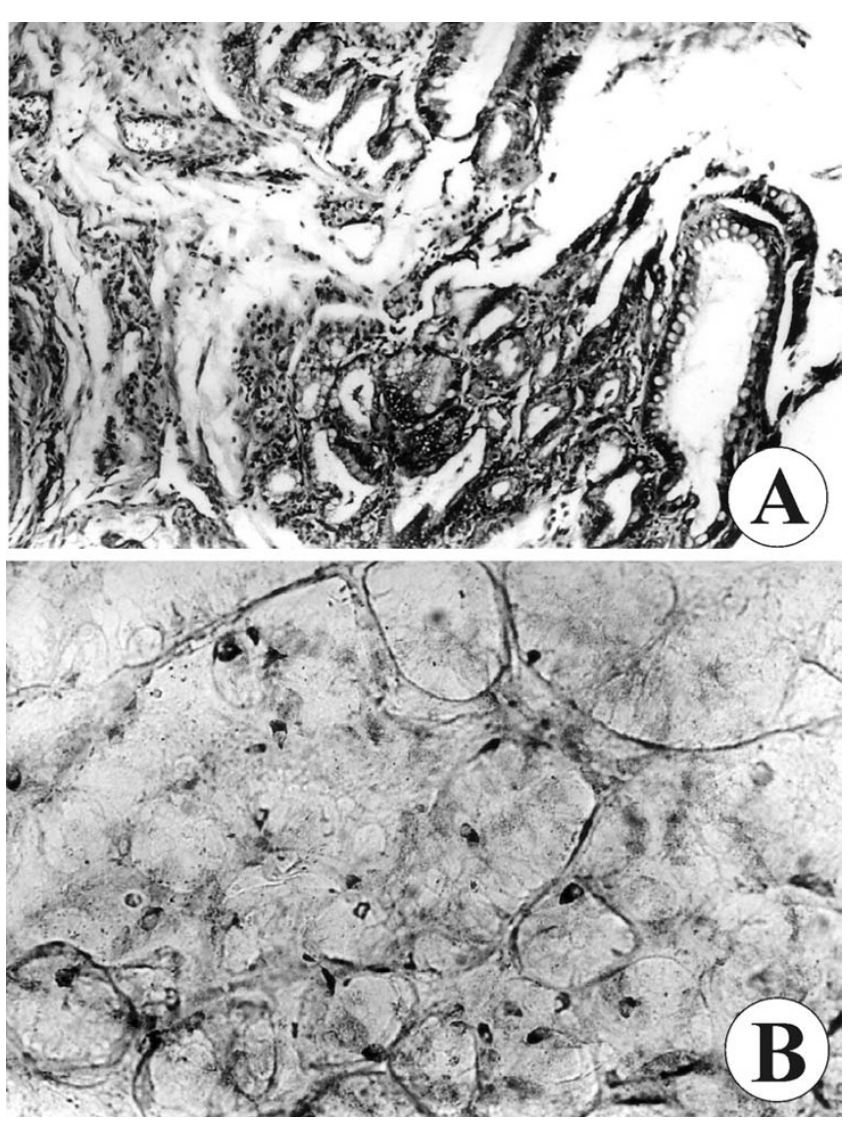

Figure 3

The different types of cells observed during microscopic examination. (A) Goblet cells and (B) serotoninpositive endocrine cells.

mucosa, duodenal mucosa and small intestinal mucosa with goblet cells.

The gastrointestinal tract and the accessory digestive organs develop from modifications of the primitive gut, which elongate and differentiate into the foregut, midgut and hindgut. The foregut includes the pharynx, mouth, esophagus, stomach, hepatic cells and bile ducts, pancreatic islands and the duodenum [8]. From our findings, it can be inferred that the observed cyst arose from the foregut very early in the development of the gastrointestinal tract. This is consistent with the gastric and intestinal mucosa found and the absence of hepatic and biliary tissue in the cyst lining.

Endocrine cells are widely distributed in the epithelial layer in organs that originate from the primitive gut [9]. The ontogeny of the gastrointestinal neuroendocrine system includes the simultaneous development of gut endocrine cells and neurons of the peripheral nervous system [10]. The first endocrine cells in the gut appear no later 
than the 10th week of gestation in both the stomach and the intestine [11]. Epithelial cells containing gastrin and somatostatin are found during the early period of gastric and small-intestinal development. The small-intestinal epithelium also contains bombesin-positive cells [12].

The clinical presentation of a heterotopic gastrointestinal cyst is non-specific and is associated with chronic cholecystitis. The clinical symptoms are generally biliary attacks, nausea and vomiting [13].

The most interesting finding of this report is that tissue from a common origin can be present in an uncommon anatomical position and mimic a completely different pathogenesis.

\section{Conclusion}

From a surgical point of view, the presence of a gastroenteric cyst in the region of the gallbladder and biliary pathways should be recognized as a random formation that has to be differentiated from other tumor lesions.

In our case we observed the presence of a great variety of endocrine cells in the cyst mucosa, which can normally be detected in the stomach and intestine. To the best of the authors' knowledge, there are no other reports of the presence of endocrine cells in a gastric cyst. Their simultaneous occurrence in the cyst shows that the epithelial and endocrine cell components of the gastrointestinal mucosa develop at the same time, and the latter support the development of the former by the release of proper hormones and growth factors $[10,11]$.

\section{Competing interests}

The authors declare that they have no competing interests.

\section{Authors' contributions}

$\mathrm{AP}$ conceived the idea for the study and made a substantial contribution to the sequence alignment and possible sources for the references, as well as drafting the definitive version of the manuscript. MG contributed to the interpretation of the histological section and immunochemistry study of the case. $\mathrm{AD}$ and $\mathrm{DS}$ made a substantial contribution to the embryologic section, as well as taking and interpreting the photographs. All authors edited and approved the final version of the manuscript.

\section{Consent}

Written informed consent was obtained from the patient for publication of this case report and any accompanying images. A copy of the written consent is available for review by the Editor-in-Chief of this journal.

\section{Acknowledgements}

This work was supported in part by the Thracian University, Medical Faculty, University Hospital, Stara Zagora, Bulgaria.

\section{References}

I. Xeropotamos N, Skopelitou AS, Batsis Ch, Kappas AM: Heterotopic gastric mucosa together with intestinal metaplasia and moderate dysplasia in the gallbladder: report of two clinically unusual cases with literature review. Gut 200I, 48:719-723.

2. Isik I, Sezer C, Dursun A: Gastric heterotopia in the gallbladder: a case report. Turk J Gastroenterol 2002, I 3: I72-I74.

3. Wakiyama S, Yoshimura K, Shimada M, Kajiyama K, Sugimachi K: Heterotopic gastric mucosa in a gallbladder with an anomalous union of the pancreatobiliary duct: a case report. Hepatogastroenterology 1998, 45: I488-|49I.

4. Yoon AJ, Cowles RA, Stylianos S, O'Toole KM: Heterotopic gastric mucosa in the gallbladder: a rare cause of massive hemobilia. J Pediatr Gastroenterol Nutr 2005, 40:606-608.

5. Martone $\mathrm{CH}$, Wolf SM, Wesley RK: Heterotopic gastrointestinal cyst of the oral cavity. J Oral Maxillofac Surg I992, 50: I340-I 342.

6. Lauwers H, Capoen J, De Baets F, Azou M: Gastroenteric cyst. J Belge Radiol 1993, 76:247-248.

7. Laraja RD, Rothenberg RE, Chapman J, Imran-ul-Haq, Sabatini MT: Foregut duplication cyst: a report of a case. Am Surg 1995, 6 I (9):840-84 I.

8. Gray H: Embryology. In Gray's Anatomy 37th edition. Edited by: Williams PL, Warwick R, Dyson M, Bannister LH. London: Churchill Livingstone; 1989:231-238.

9. Kurumaya $\mathrm{H}$, Goroku $\mathrm{O}, \mathrm{Nakanuma} \mathrm{Y}$ : Endocrine cells in the intrahepatic biliary tree in normal livers and hepatolithiasis. Arch Pathol Lab Med 1989, I I 3: |43-147.

10. Falkmer S: Phylogeny and ontogeny of the neuroendocrine cells of the gastrointestinal tract. Endocrinol Metab Clin North Am 1993, 22:731-752.

II. Facer P, Bishop AE, Cole GA, Aitchison M, Kendall $\mathrm{CH}$, van Aswegen G, Penketh RJ, Rodek CH, McKeever P, Polak JM: Developmental profile of chromogranin, hormonal peptides, and 5-hydroxytryptamine in gastrointestinal endocrine cells. Gastroenterology 1989, 97:48-57.

12. Gaidar YA, Lepekhin EA, Sheichetova GA, Witt M: Distribution of $\mathbf{N}$-cadherin and NCAM in neurons and endocrine cells of the human embryonic and fetal gastroenteropancreatic system. Acta Histochem 1998, 100:83-97.

13. Tavli L, Belviranli M, Erikoglu M, Esen H, Toy H: Gastric heterotopia together with intestinal metaplasia in the gallbladder: case report and review of literature. Turk J Gastroenterol 2005, 16:160-162.

Publish with Bio Med Central and every
scientist can read your work free of charge
"BioMed Central will be the most significant development for
disseminating the results of biomedical research in our lifetime. "
Sir Paul Nurse, Cancer Research UK
Your research papers will be:
- available free of charge to the entire biomedical community
• peer reviewed and published immediately upon acceptance
- cited in PubMed and archived on PubMed Central
- yours - you keep the copyright
Submit your manuscript here:
http://www.biomedcentral.com/info/publishing_adv.asp

